\title{
Development of Photochemical DNA/RNA Manipulation Toward Its Application for Nanotechnology
}

\author{
Kenzo Fujimoto ${ }^{1,2, *}$, Hideaki Yoshino ${ }^{3}$, Tomoko Ohtake ${ }^{1}$, Yoshinaga Yoshimura ${ }^{1,2}$ and \\ Isao Saito ${ }^{4}$ \\ ${ }^{1}$ School of Materials Science, Japan Advanced Institute of Science and Technology, 1-1 Asahidai, Nomi, \\ Ishikawa 923-1292, Japan \\ Fax: 81-761-51-1671, e-mail: kenzo@jaist.ac.jp \\ ${ }^{2}$ Innovation Plaza Ishikawa, Japan Science and Technology Agency, 2-13 Asahidai, Nomi, Ishikawa \\ 923-1211, Japan \\ ${ }^{3}$ Department of Synthetic Chemistry and Biological Chemistry, Faculty of Engineering, Kyoto University, \\ Kyoto, 606-8501, Japan \\ ${ }^{4}$ NEWCAT Institute, School of Engineering, Nihon University, Koriyama 963-8642, Japan
}

\begin{abstract}
We describe a light-controlled template-directed reversible DNA photoligation via carbazole tethered 5-carboxyvinyluracil. Carbazole tethered 5-carboxyvinyl-2'-deoxyuridine $\left({ }^{\mathrm{CV}} \mathrm{U}\right)$-containing oligodeoxynucleotide (ODN) can be ligated by irradiation at $366 \mathrm{~nm}$ in the presence of template ODN, and the ligated ODN can be split by irradiation at $366 \mathrm{~nm}$ in the absence of the template ODN.
\end{abstract}

Key words: DNA recognition, ligation reactions, carbazole, photosensitizer, photochemistry

\section{Introduction}

Template-directed DNA ligation proceeding under the control of specific DNA templates is an important technique for potential synthetic and nano-technological applications [1]. In recent years, template-directed DNA ligation has developed as a useful tool with applications such as nucleic acid detection [2], sequence-specific small-molecule synthesis [3], and nano-architecture construction [4]. While many methods for template-directed chemical ligation of DNA via a native phosphodiester bond or non-native linkages have been demonstrated, only a few exist for photoinduced non-enzymatic chemical ligation. The merit of photochemical ligation that avoids the need for additional reagents is obvious, since their actions are subsequently controllable within space and time by selecting proper irradiation methods. However, these methods also have serious problems in terms of practical applications, such as low photoligation yields, the use of short wavelengths injurious to other components, the occurrence of undesirable photocrosslinking reactions and the lack of photoreversibility. In our continuing efforts to develop a novel method for template-directed DNA photoligation, we demonstrated an efficient and reversible template-directed photoligation of ODNs using 5 -substituted pyrimidine analogues [5]. Using ODNs containing modified pyrimidine nucleosides at the $5^{\prime}$ or $3^{\prime}$ end, we have succeeded in synthesizing complex DNA structures, such as tandem ligated DNA, branched DNA or padlocked plasmid DNA at the desired sites, and the reversible photocleavage of the ligated DNA by photoirradiation at a shorter wavelength (Figure 1) [6]. Therefore, our photoligation system using vinyl-substituted pyrimidine nucleosides can be a powerful tool for easy and accurate DNA handling, triggering the development of new nanotechnology applications.

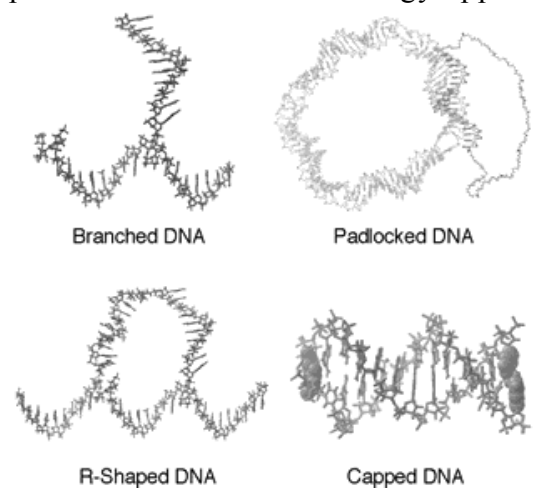

Fig. 1 Various DNA structures constructed by using photoligation.

In this manipulation, the ligated ODN can be split site-selectively to regenerate the parent ODN by photoirradiation at $302 \mathrm{~nm}$. However, photoirradiation at $302 \mathrm{~nm}$ also results in fatal damage to normal DNA, due to the formation of pyrimidine dimer [7]. Thus one problem associated with template-directed reversible DNA photoligation is the fact that the efficiency of repeated DNA photoligation declines gradually due to DNA photodamage. The development of a photoligation system, capable of being repeatedly ligated and split, would represent a useful 
technique for DNA nanotechnology such as DNA nanoarchitecture [8], DNA computing [9], and DNA-based memory [10]. $N$-Methylcarbazole was known to have singlet excited-state electron donors, and featured the (6-4) pyrimidinepyrimidone lesion repaired by photosensitized reductive electron-transfer reactions [11]. Herein, we have overcome this problem by using carbazole sensitizer tethered ${ }^{\mathrm{CV}} \mathrm{U}$-containing ODN. We demonstrated that control of photoligation and photosplitting at $366 \mathrm{~nm}$ is possible, both with and without the ODN template.

\section{Experimental}

$5^{\prime}-O-(4$,

4'-Dimethoxytrityl)-5-(E)-(2-carboxy-vinyl)-2'-d eoxyuridine (4).

To a solution of $3(500 \mathrm{mg}, 1.68 \mathrm{mmol})$ in dry pyridine $(10 \mathrm{ml})$ was added $4,4^{\prime}$-dimethoxytrityl chloride $(681 \mathrm{mg}, 2.01 \mathrm{mmol})$ and $N, N$-dimethylaminopyridine $(20 \mathrm{mg}, 0.168 \mathrm{mmol})$ cooling by ice bath and the solution was stirred for $18 \mathrm{~h}$ at an ambient temperature. After quenching the reaction by adding methanol, the mixture was evaporated to dryness in vacuo. The residue was extracted with ethylacetate $(20 \mathrm{~mL} x$ $3)$ and water $(30 \mathrm{~mL})$, and the organic layer was collected, dried over sodium sulfate, filtered, and evaporated to dryness under reduced pressure. The crude product was purified by silica gel column chromatography (hexane : ethylacetate = $1: 3)$ to afford $4(533 \mathrm{mg}, 55 \%)$ as a white solid. ${ }^{1} \mathrm{H}-\mathrm{NMR}\left(400 \mathrm{MHz}, \mathrm{DMSO}-d_{6}\right) \delta 11.69$ (bs, $1 \mathrm{H}$, $\mathrm{NH}), 8.04(\mathrm{~s}, 1 \mathrm{H}, 6-\mathrm{H}), 7.35(\mathrm{~d}, 1 \mathrm{H}, J=15.6 \mathrm{~Hz}$, vinyl), 6.86-6.83 (m, 4H, H-ortho to $\left.\mathrm{OCH}_{3} \times 4\right)$, $6.78(\mathrm{~d}, 1 \mathrm{H}, J=15.6 \mathrm{~Hz}), 6.16(\mathrm{t}, 1 \mathrm{H}, J=7.2 \mathrm{~Hz}$, $\left.1^{\prime}-\mathrm{H}\right), 5.30\left(\mathrm{bs}, 1 \mathrm{H}, 3^{\prime}-\mathrm{OH}\right), 4.23-4.21(\mathrm{~m}, 1 \mathrm{H}$, $\left.3^{\prime}-\mathrm{H}\right), 3.90-3.86\left(\mathrm{~m}, 1 \mathrm{H}, 4^{\prime}-\mathrm{H}\right), 3.70(\mathrm{~d}, 6 \mathrm{H}, J=$ $\left.2.8 \mathrm{~Hz}, \quad \mathrm{OCH}_{3}\right), \quad 3.24-3.13 \quad\left(\mathrm{~m}, \quad 2 \mathrm{H}, \quad 5^{\prime}-\mathrm{H}\right)$, 2.35-2.15(m, 2H, 2'-H); HRMS: (positive ion FAB) calcd. for $\mathrm{C}_{33} \mathrm{H}_{32} \mathrm{~N}_{2} \mathrm{O}_{9}\left[(\mathrm{M}+\mathrm{H})^{+}\right] 600.2107$, found 600.2106 .

$5^{\prime}-O-\left(4,4^{\prime}-\right.$ Dimethoxytrityl)-5-(E)-(2-(6-(2-carba zol-9-yl-acetylamino)-hexylamino)-carbonylvinyl )-2'-deoxyuridine (5).

To a solution of $4(300 \mathrm{mg}, 0.50 \mathrm{mmol})$ in acetonitrile $(20 \quad \mathrm{~mL})$ was added $\mathrm{N}$-hydroxysuccinimide $(75.0 \mathrm{mg}, 0.60 \mathrm{mmol})$ and 1-ethyl-3-(3'-dimethyl aminopropyl) carbodiimide hydrochloride salt $(114 \mathrm{mg}, 0.60$ mmol) cooling by ice bath, the solution was stirred for $18 \mathrm{~h}$ at an ambient temperature, then $N$-(6-amino-hexyl)-2-carbazol-9-yl-acetamide $(161 \mathrm{mg}, 0.50 \mathrm{mmol})$ was added and stirred for 6 h. The precipitate was removed by filtration, and evaporated. The residue was extracted with chloroform $(20 \mathrm{~mL} \times 3)$ and water $(30 \mathrm{~mL})$ and washed with brine $(20 \mathrm{~mL} \times 2)$. The organic layer was collected, dried over sodium sulfate, filtered, and evaporated to dryness under reduced pressure. The crude product was dissolved into ethylacetate and the solution was added dropwise to excess hexane for trituration. The white precipitate $\mathbf{5}$
(348 mg, 77\%) was dried in vacuo. ${ }^{1} \mathrm{H}-\mathrm{NMR}(400$ $\left.\mathrm{MHz}, \mathrm{DMSO}-d_{6}\right) \delta 11.62(\mathrm{bs}, 1 \mathrm{H}, \mathrm{NH}), 8.13$ (d, $2 \mathrm{H}, J=7.6 \mathrm{~Hz}), 7.94(\mathrm{~s}, 1 \mathrm{H}, 6-\mathrm{H}), 7.49(\mathrm{~d}, 2 \mathrm{H}, J$ $=8.0 \mathrm{~Hz}), 7.41-7.35(\mathrm{~m}, 4 \mathrm{H}), 7.29-7.16(\mathrm{~m}, 9 \mathrm{H})$, $7.11(\mathrm{~d}, 1 \mathrm{H}, J=15.6 \mathrm{~Hz}$, vinyl-H), $7.05(\mathrm{~d}, 1 \mathrm{H}, J$ $=15.6 \mathrm{~Hz}$, vinyl-H), 6.87-6.84 (m, 4H), $6.16(\mathrm{t}$, $\left.1 \mathrm{H}, J=6.8 \mathrm{~Hz}, 1^{\prime}-\mathrm{H}\right), 5.30(\mathrm{~d}, 1 \mathrm{H}, J=4.4 \mathrm{~Hz}$, 3'-OH), $4.99(\mathrm{~s}, 2 \mathrm{H}), 4.23-4.19\left(\mathrm{~m}, 1 \mathrm{H}, 3^{\prime}-\mathrm{H}\right)$, 3.89-3.84 (m, $\left.1 \mathrm{H}, 4^{\prime}-\mathrm{H}\right), 3.70\left(\mathrm{~s}, 3 \mathrm{H}, \mathrm{OCH}_{3}\right), 3.69$ $\left(\mathrm{s}, 3 \mathrm{H}, \mathrm{OCH}_{3}\right), 3.18-3.12(\mathrm{~m}, 2 \mathrm{H}), 3.12-3.05(\mathrm{~m}$, $2 \mathrm{H}), 2.34-2.13\left(\mathrm{~m}, 2 \mathrm{H}, 2^{\prime}-\mathrm{H}\right), 1.43-1.37(\mathrm{~m}, 4 \mathrm{H})$, 1.28-1.23 (m, 4H); HRMS: (positive ion FAB) calcd. for $\mathrm{C}_{53} \mathrm{H}_{56} \mathrm{~N}_{5} \mathrm{O}_{9}\left[(\mathrm{M}+\mathrm{H})^{+}\right] 906.4078$, found 906.4069

$5^{\prime}-O-\left(4,4^{\prime}\right.$-Dimethoxytrityl)-3'-O-[2-cyanoethoxy -(N,N-diisopropylamino)-phosphino]-5-(E)-(2-(6(2-carbazol-9-yl-acetylamino)-hexylamino)-carbo nylvinyl)-2' -deoxyuridine (6).

To a solution of $5(300 \mathrm{mg}, 0.33 \mathrm{mmol})$ in acetonitrile $(3 \mathrm{~mL})$ was added $N, \quad N, N^{\prime}$, $N^{\prime}$-tetraisopropylaminophosphorodiamidite $\quad(200$ $\mu \mathrm{L}, 0.66 \mathrm{mmol})$, then $1 H$-tetrazole $(35.0 \mathrm{mg}, 0.50$ mmol) dissolved in acetonitrile $(1 \mathrm{~mL})$. After being stirred for $1 \mathrm{~h}$ at an ambient temperature under nitrogen, the reaction mixture was concentrated, residue extracted with ethylacetate $(20 \mathrm{~mL} \times 3)$ and saturated $\mathrm{NaHCO}_{3}$ aq. $(20 \mathrm{~mL})$, and the organic layer collected, dried over sodium sulfate, filtered, and evaporated to dryness under reduced pressure. The crude product $6(365 \mathrm{mg}$, quant.) was dissolved in dry acetonitrile, coevaporated three times, and then used for the automated DNA synthesizer without further purification.

Photoligation of DNA as monitored by PAGE.

A solution (total volume $10 \mu \mathrm{L}$ ) containing target ODN and modified ODN $(7 \mu \mathrm{M})$, ${ }^{32} \mathrm{P}-5$ '-end-labeled target ODN $(7 \mu \mathrm{M})$, and template ODN $(9 \mu \mathrm{M})$ in $50 \mathrm{mM}$ sodium acetate buffer ( $\mathrm{pH} 5.0$ ) and $1 \mathrm{M} \mathrm{NaCl}$ was irradiate with transilluminator $(366 \mathrm{~nm})$ at a distance of $3-5 \mathrm{~cm}$ at $0{ }^{\circ} \mathrm{C}$ for $6 \mathrm{~h}$.

\section{Results and discussion}

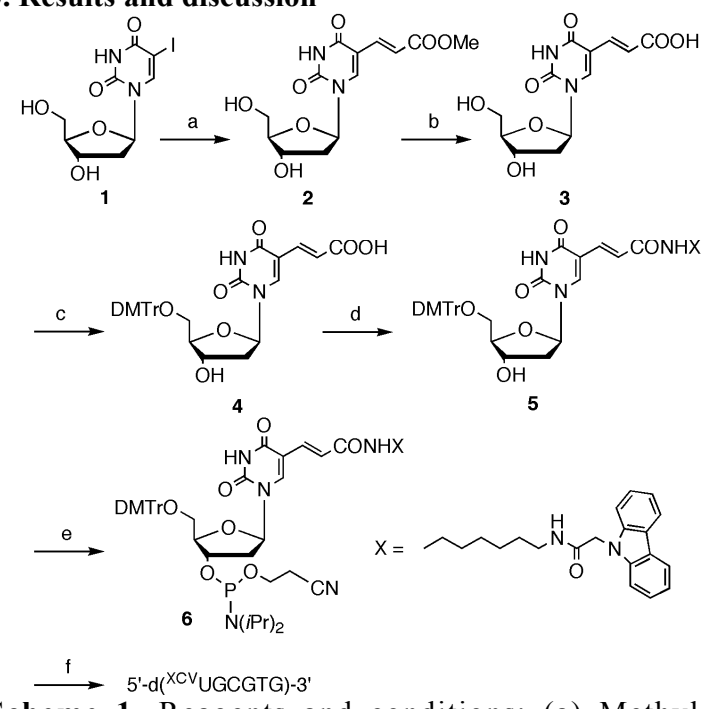

Scheme 1. Reagents and conditions: (a) Methyl 
acrylate, $\mathrm{Pd}(\mathrm{OAc})_{2}, \mathrm{PPh}_{3}, \mathrm{NEt}_{3}$, dioxane, reflux, 1 h, 70\%; (b) $\mathrm{NaOH}, \mathrm{HCl}, \mathrm{H}_{2} \mathrm{O}$, room temperature, $3 \mathrm{~h}, 81 \%$; (c) DMTrCl, DMAP, pyridine, room temperature, $18 \mathrm{~h}, 55 \%$; (d) NHS, EDCl, $\mathrm{XNH}_{2}$, $\mathrm{CH}_{3} \mathrm{CN}$, room temperature, $18 \mathrm{~h}, 77 \%$; (e) $\left[(i \mathrm{Pr})_{2} \mathrm{~N}\right]_{2} \mathrm{POCH}_{2} \mathrm{CH}_{2} \mathrm{CN}$, tetrazole, $\mathrm{CH}_{3} \mathrm{CN}$, room temperature, $1 \mathrm{~h}$, quant; (f) DNA synthesizer.

The phosphoramidite of carbazole tethered ${ }^{\mathrm{CV}} \mathrm{U}$ was synthesized from 5-iodo-2'-deoxyuridine (Scheme 1). Compound 3 was prepared according to a method reported in literature [12]. These modified ODNs were synthesized according to the standard phosphoramidite chemistry on a DNA synthesizer, using phosphoramidite of carbazole tethered ${ }^{\mathrm{CV}} \mathrm{U}$. These modified ODNs were characterized by a nucleoside composition and MALDI-TOF-MS. Figure 2 shows a schematic chart for the light-controlled reversible DNA photoligation via carbazole tethered modified ODNs. When ODN 1, 5'-d( $\left.{ }^{\mathrm{XCV}} \mathrm{UGCGTG}\right)-3^{\prime}$, and ${ }^{32} \mathrm{P}-5^{\prime}$ '-end-labeled 6-mer ODN 2, $5^{\prime}-\mathrm{d}($ CTTCGT)-3', were irradiated at $366 \mathrm{~nm}$ for $6 \mathrm{~h}$ at $0{ }^{\circ} \mathrm{C}$ in the presence of template 12 -mer ODN 3, 5'-d(CACGCAACGAAG)-3', the expected ligated 12-mer ODN 4 was produced at an $89 \%$ yield, as determined by the densitometric assay of PAGE (Figure 3, lane 3) [12]. As shown in Figure 4, The enzymatic digestion of isolated ODN 4, obtained from HPLC purification, showed the formation of $\mathrm{dC}, \mathrm{dG}$, and $\mathrm{dT}$ in a ratio of $3: 4: 3$ together with ${ }^{\mathrm{XCV}} \mathrm{U}-\mathrm{dT}$ photoadduct, which was confirmed by MALDI-TOF-MS (calcd. 846.89 for $[\mathrm{M}-\mathrm{H}]^{-}$; found 846.81) [13]. As shown in Figure 5, the structure of ${ }^{\mathrm{XCV}} \mathrm{U}-\mathrm{dT}$ photoadduct obtained from HPLC purification was assigned as a cis-syn [2+2] adduct on the basis of the spectroscopic data, including ${ }^{1} \mathrm{H}-{ }^{1} \mathrm{H}$ COSY and NOESY. In the case of photoirradiation at $366 \mathrm{~nm}$ in the presence of ODN 3 at $70{ }^{\circ} \mathrm{C}$, no photoligated product was observed (Figure 3, lane 5). This result clearly shows that the photoligation via ODN 1 proceeded in a template-directed manner.

To examine the role of the carbazole sensitizer in reversible DNA photoligation, photoirradiation at $366 \mathrm{~nm}$ of ligated ODN 4 was performed and analyzed by $15 \%$ PAGE. When isolated ODN 4 was irradiated at $366 \mathrm{~nm}$ for $6 \mathrm{~h}$ in the absence of template ODN 3, we observed the appearance of ODN 2 in $91 \%$ yield, as determined by PAGE, along with the disappearance of ODN 4 (Figure 6, lane 6).

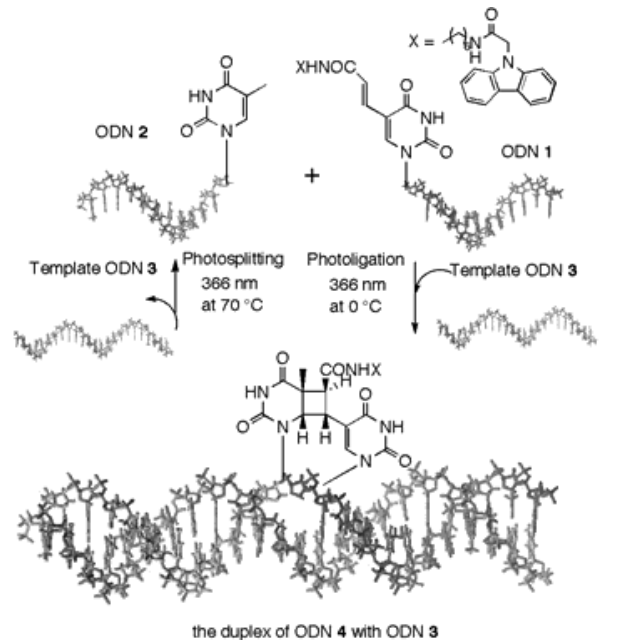

Fig. 2 Schematic representation of the light-controlled reversible DNA photoligation.

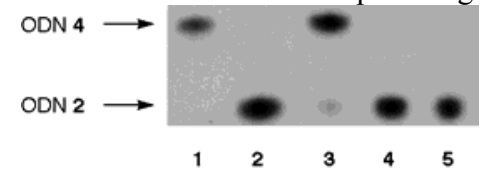

Fig. 3 Autoradiogram of a denaturing $15 \%$ polyacrylamide gel electrophoresis of a photoreaction of ${ }^{32} \mathrm{P}-5$ '-end-labeled ODN 2 (7 $\mu \mathrm{M})$ and ODN $1(7 \mu \mathrm{M})$ and template ODN 3 (9 $\mu \mathrm{M})$ in a solution of $\mathrm{NaCl}(1 \mathrm{M})$ and sodium acetate buffer ( $50 \mathrm{mM}, \mathrm{pH} 5.0$ ). Lane 1 , authentic ${ }^{32} \mathrm{P}$-labeled photoligated product; Lane 2, before photoligation; Lane 3, irradiation at $366 \mathrm{~nm}$ for 6 $\mathrm{h}, 0{ }^{\circ} \mathrm{C}, 89 \%$ yield; Lane 4 , irradiation at $366 \mathrm{~nm}$ for $6 \mathrm{~h}$ without template ODN 3; Lane 5, irradiation at $366 \mathrm{~nm}$ for $6 \mathrm{~h}, 70^{\circ} \mathrm{C}$.

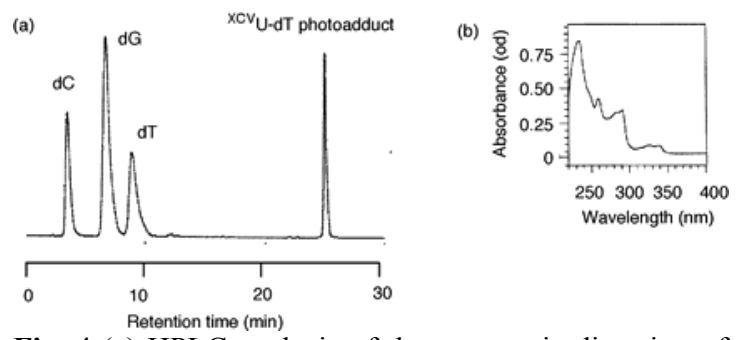

Fig. 4 (a) HPLC analysis of the enzymatic digestion of isolated ODN 4. (b) UV spectrum of ${ }^{\mathrm{XCV}} \mathrm{U}-\mathrm{T}$ adduct. 

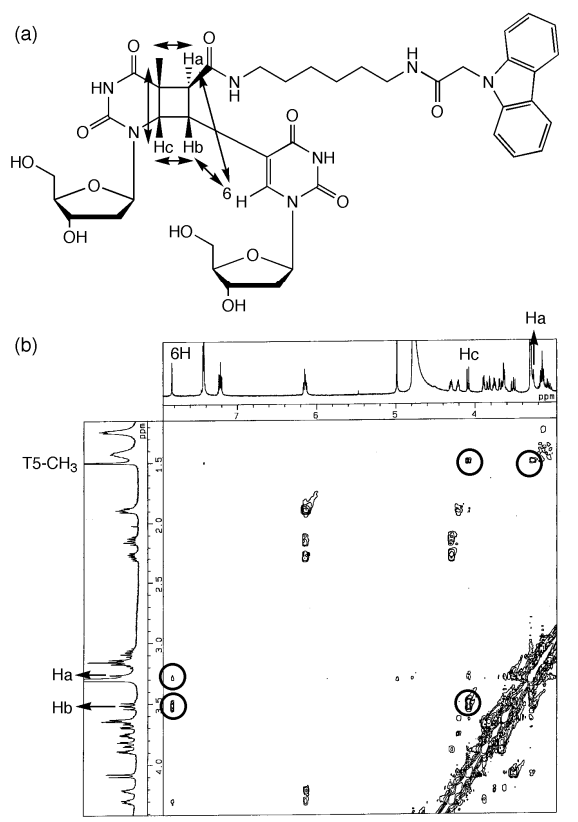

Fig. 5 (a) Structure of ${ }^{\mathrm{XCV}} \mathrm{U}-\mathrm{dT}$ photoadduct. (b) NOESY spectrum of ${ }^{\mathrm{XCV}} \mathrm{U}-\mathrm{dT}$ photoadduct.

To examine the environment of the carbazole in a DNA duplex, UV melting profiles were obtained. The $T_{\mathrm{m}}$ value $\left(46.8{ }^{\circ} \mathrm{C}\right)$ of the duplex of ODN 4 with ODN 3 was higher than that of ODN 3 and the photoligated product from ${ }^{\mathrm{CV}} \mathrm{U}$-containing photoligated product from $\left(5^{\prime}-\mathrm{d}\left(\mathrm{CTTCGT}<>^{\mathrm{CV}} \mathrm{UGCGTG}\right)-3^{\prime}\right) \quad\left(44.9{ }^{\circ} \mathrm{C}\right)$. Furthermore, we performed fluorescence titration of ODN 4 by ODN 3 in order to study the environment of the carbazole [14]. The fluorescence intensity of the carbazole was gradually increased by 2.7 -fold compared to the single-stranded ODN 4. These results suggested that the carbazole in the duplex ODN 4 with ODN 3 intercalated between bases and kept away from the photoligated position, meaning DNA photoligation at $366 \mathrm{~nm}$ can proceed effectively in the duplex without carbazole-sensitized photosplitting. An important feature of this reversible DNA photoligation is the fact that photoligation and photosplitting at $366 \mathrm{~nm}$ can be controlled by the difference between the single-stranded and duplex structures. The pathway in Scheme 2 illustrates the mechanistic proposal for the sensitized photosplitting at 366 $\mathrm{nm}$ and the photosplitting at $302 \mathrm{~nm}$. In the sensitized photosplitting, carbazole absorbs a photon and the electron flow is from the sensitizer to the photoligated site. Thus the introduction of carbazolyl group to ${ }^{\mathrm{CV}} \mathrm{U}$ is important to improve the reactivity of photosplitting.

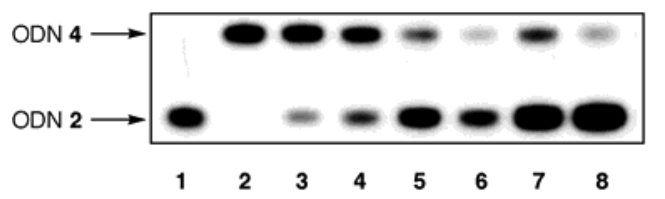

Fig. 6 Autoradiogram of a denaturing $15 \%$ polyacrylamide gel electrophoresis of photoreaction of ${ }^{32} \mathrm{P}-5$ '-end-labeled ODN 4 (5 $\mu \mathrm{M})$. Lane 1: authentic ${ }^{32} \mathrm{P}$-labeled ODN 2; Lane 2: before photosplitting; Lane 3: $366 \mathrm{~nm}$ irradiation for $30 \mathrm{~min}$., 14\% yield; Lane 4: 366 $\mathrm{nm}$ irradiation for 60 min., $31 \%$ yield; Lane 5: $366 \mathrm{~nm}$ irradiation for $2 \mathrm{~h}, 82 \%$ yield; Lane 6 : $366 \mathrm{~nm}$ irradiation for $6 \mathrm{~h}, 91 \%$ yield; Lane 7 : $366 \mathrm{~nm}$ irradiation for $30 \mathrm{~min}$., in water: $\mathrm{MeCN}=$ $1: 1,84 \%$ yield; Lane 8: $366 \mathrm{~nm}$ irradiation for 60 min., in water: $\mathrm{MeCN}=1: 1,96 \%$ yield.
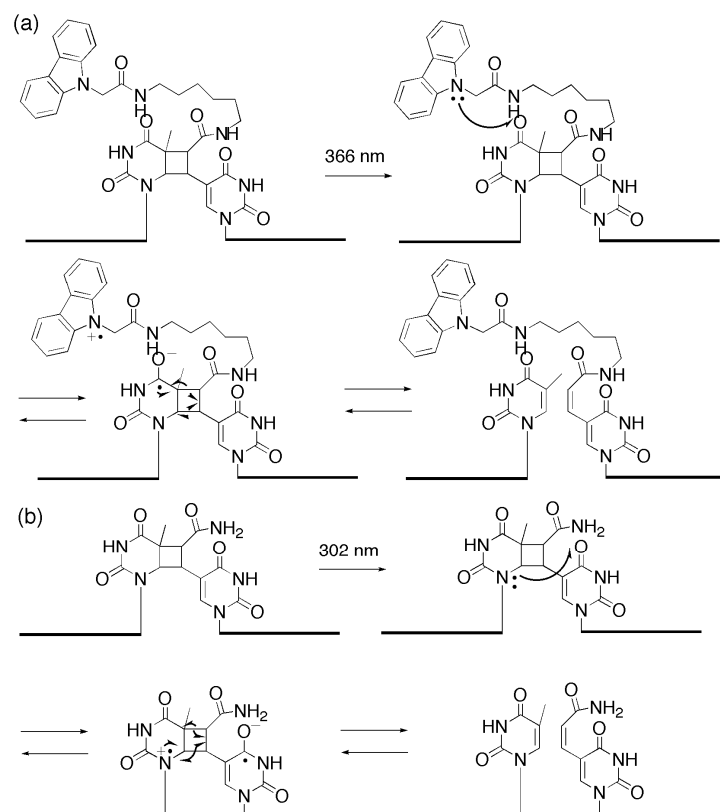

Scheme 2. (a) Carbazole-sensitized photosplitting of the photoligated ODN. (b) Photosplitting of the photoligated $\mathrm{ODN}$ at $302 \mathrm{~nm}$.

\section{Conclusion}

In conclusion, we have demonstrated the fact that carbazole tethered ${ }^{\mathrm{CV}} \mathrm{U}$-containing ODN can be ligated by irradiation at $366 \mathrm{~nm}$ in the presence of template ODN, and that the ligated ODN can be split by irradiation at $366 \mathrm{~nm}$ in the absence of template ODN. This light-controlled template-directed reversible DNA photoligation may provide a unique methodology for DNA engineering, DNA nanotechnology, and photochemical DNA manipulation.

\section{Acknowledgement}

This work was supported by a Grant-in-Aid for Science Research from the Ministry of Education, Culture, Sports, Science and Technology, Japan.

\section{References}

[1] (a) C. Bohler, P. E. Nielsen and L. E. Orgel, Nature, 376, 578-581 (1995). (b) Y. Xu, N. B. Karalkar and E. T. Kool, Nat. Biotechnol., 19, 148-152 (2001).

[2] A. P. Silverman and E. T. Kool, Chem. Rev., 106, 3775-3789 (2006).

[3] Z. J. Gartner, M. W. Kanan and D. R. Liu, J. Am. Chem. Soc., 124, 10304-10306 (2002).

[4] K. V. Gothelf and R. S. Brown, Chem. Eur. J., 
11, 1062-1069 (2005).

[5] (a) K. Fujimoto, S. Matsuda, N. Takahashi and I. Saito, J. Am. Chem. Soc., 122, 5646-5647 (2000). (b) Y. Yoshimura, Y. Noguchi, H. Sato and K. Fujimoto, ChemBioChem, 7, 598-601 (2006). (c) S. Ogasawara and K. Fujimoto, Angew. Chem., Int. Ed., 45, 4512-4515 (2006).

[6] (a) K. Fujimoto, Y. Yoshimura, T. Ikemoto, A. Nakazawa, M. Hayashi and I. Saito, Chem. Commun., 3177-3179 (2005). (b) S. Ogasawara, Y. Yoshimura, M. Hayashi, I. Saito and K. Fujimoto, Bull. Chem. Soc. Jpn., 80, 2124-2130 (2007). (c) K. Fujimoto, S. Matsuda, Y. Yoshimura, T. Ami and I. Saito, Chem. Commun., 2968-2970 (2007).

[7] T. Carell, L. T. Burgdorf, L. M. Kundu and M. Cichon, Curr. Opin. Chem. Biol., 5, 491-498 (2001).

[8] (a) W. M. Shih, J. D. Quispe and G. F. Joyce, Nature, 427, 618-621 (2004). (b) R. P. Goodman, I. A. T. Schaap, C. F. Tardin, C. M. Erben, R. M. Berry, C. F. Schmidt and A. J. Turberfield, Science, 310, 1661-1665 (2005).

[9] Y. Weizmann, R. Elnathan, O. Lioubashevski and I. Willner, J. Am. Chem. Soc., 127, 12666-12672 (2005).

[10] J.-S. Shin and N. A. Pierce, Nano Lett., 4, 905-909 (2004).

[11] A. Joseph, G. Prakash and D. E. Falvey, J. Am. Chem. Soc., 122, 11219-11225 (2000).

[12] M. Ashwell, A. S. Jones, A. Kumar, J. R. Sayers, R. Walker, T. Sakuma and E. De Clercq, Tetrahedron, 43, 4601-4608 (1987).

[13] ${ }^{\mathrm{XCV}} \mathrm{U}-\mathrm{dT}$ photoadduct: UV $\left(\mathrm{H}_{2} \mathrm{O}\right) \lambda(\varepsilon) 366$ $\mathrm{nm}\left(36 \mathrm{M}^{-1} \mathrm{~cm}^{-1}\right)$.

[14] R. M. Hartshorn and J. K. Barton, J. Am. Chem. Soc., 114, 5919-5925 (1992).

(Received December 10, 2008; Accepted April 17, 2009) 